\title{
Combination antifungal therapy for invasive pulmonary aspergillosis
}

\author{
Salman Abdulaziz, Hamdan Al Jahdali, Salim Baharoon
}

Department of Internal Medicine, King Abdulaziz Medical City, King Fahad National Guard Hospital, Riyadh, Saudi Arabia

\section{Correspondence to} Dr Salman Abdulaziz, dr-salman@hotmail.com
To cite: Abdulaziz $S$ Al Jahdali $\mathrm{H}$, Baharoon $\mathrm{S}$ BMJ Case Reports Published online: 14 December 2012 doi:10.1136/bcr-2012007824

\section{DESCRIPTION}

A 58-year-old man with a history of AIDS and recurrent non-Hodgkin's lymphoma had 1-week complaint of fever, productive cough and chest pain 2 weeks after chemotherapy. He was on antiretroviral triple therapy and antibiotics, but with no response. Physical examination was significant for tachyponea and bilateral crepitations. Chest $\mathrm{x}$-ray showed right middle lobe hazy infiltrates and scattered small nodular lesions (figure 1). Laboratory data showed white cell count of $16.2 \times 10^{9} / 1$ with neutropenia, and CD4 count of 70 cells $/ \mu$ l. Bronchoscopy was performed (see video 1) and showed discrete, white coloured ulcerations of the airways. The transbronchial biopsy showed welldefined septate hyphae, dichotomously branching at an acute angle (figure 2). The overall outcome in patients with invasive pulmonary aspergillosis (IPA) is poor; however, our patient was treated with intravenous liposomal amphotericin B and voriconazole for 6 weeks, and recovered fully from his symptoms and radiological findings. He was started later on the recommended chemotherapy for lymphoma disease after introducing oral posaconazole as antifungal prophylaxis.

Clinicians are urgently seeking new strategies to remedy the poor outcome of IPA, for which the optimal therapy is unknown. Currently, voriconazole monotherapy is evidently better than polyene, but continues to be associated with unacceptably high mortality. Although some animal models and limited clinical reports suggest that combination

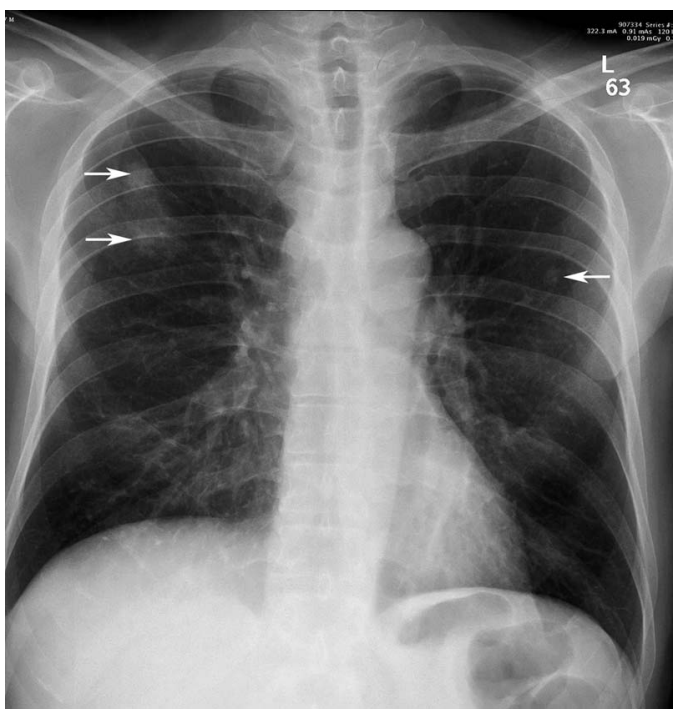

Figure 1 Chest radiograph showing right middle lobe hazy infiltrates and scattered small nodular lesions (arrows).

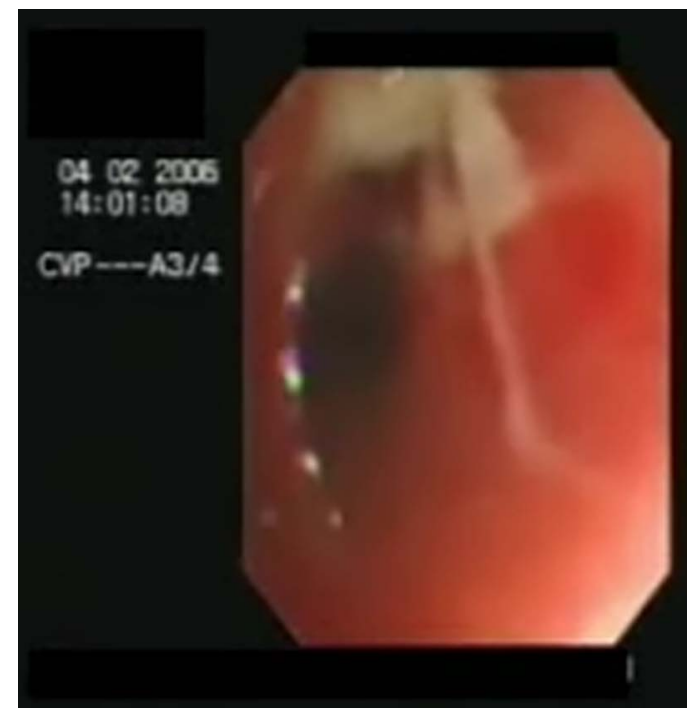

Video 1 Bronchoscopy showing the aspergillosis lesions of the airways.

antifungal therapy might offer improved outcome, the efficacy of combination therapy for IPA has not been conclusively established in controlled trials. ${ }^{1}$

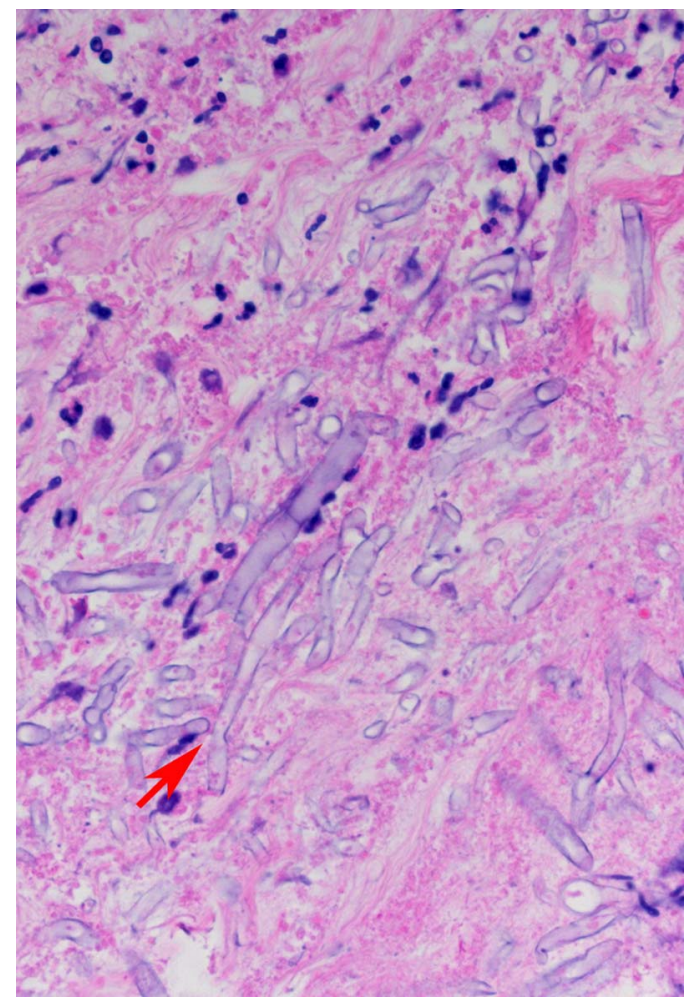

Figure 2 Septate hyphae consistent with Aspergillus infection by transbroncial biopsy (arrow). 
Potential advantages of combination antifungal therapy include a wider spectrum and potency of drug activity, more rapid antifungal effect, synergy, lowered dosing of toxic drugs and a reduced risk of antifungal resistance. ${ }^{1}$

The most frequently used antifungal combination in clinical practice is that of triazole and echinocandin, most commonly voriconazole and caspofungin. The two drugs have a synergistic interaction, simultaneously inhibiting 1,3- $\beta$-D-glucan synthesis in the fungal cell wall and ergosterol synthesis in the fungal cell membrane. ${ }^{1}$

The combination of azoles and polyene antifungal were not frequently used for fear of antagonism, although there is a lack of clinical evidence to support this concern. ${ }^{2}$ Animal model studies recently showed the combination of ambisome and voriconazole to be more effective than individual drug monotherapy. ${ }^{3}$ Askari et $a l^{4}$ tested the effectiveness and safety of this combination, and reported on its safety and effectiveness. A similar combination was also successfully used in case reports of endocarditis and invasive aspergillosis in leukaemic patient. ${ }^{5}$ More rigorous trials to test the efficacy of this combination in treating invasive aspergillosis are needed.

\section{Learning points}

- Combination antifungal therapy can be an appropriate choice for the treatment of invasive pulmonary aspergillosis (IPA).

- The combination of lipid formulated amphotericin and azoles are safe and potentially effective for the treatment of IPA.
Competing interests None.

Patient consent Obtained.

\section{REFERENCES}

1 Steinbach WJ, Juvvadi PR, Fortwendel JR, et al. Newer combination antifungal therapies for invasive aspergillosis. Med Mycol 2011;49 (Suppl 1):S77-81.

2 Scheven M, Schwegler F. Antagonistic interactions between azoles and amphotericin $\mathrm{B}$ with yeasts depend on azole lipophilia for special test conditions in vitro. Antimicrob Agents Chemother 1995;39:1779-83.

3 Silva EG, Paula CR, Dias AL, et al. Combination efficacy of voriconazole and amphotericin $B$ in the experimental disease in immunodeficient mice caused by fluconazole-resistant Cryptococcus neoformans. Mycopathologia 2011;171:261-6.

4 Askari E, Jarque I, Nicolás. Case collection study of the safety of AmBisome in association with voriconazole in the treatment of patients with invasive fungal infection. Rev Esp Quimioter 2010;23:210-12.

5 Vassiloyanakopoulos A, Falagas ME, Allamani M, et al. Aspergillus fumigatus tricuspid native valve endocarditis in a non-intravenous drug user. J Med Microbiol 2006;55(Pt 5):635-8

Copyright 2012 BMJ Publishing Group. All rights reserved. For permission to reuse any of this content visit

http://group.bmj.com/group/rights-licensing/permissions.

BMJ Case Report Fellows may re-use this article for personal use and teaching without any further permission.

Become a Fellow of BMJ Case Reports today and you can

- Submit as many cases as you like

- Enjoy fast sympathetic peer review and rapid publication of accepted articles

- Access all the published articles

- Re-use any of the published material for personal use and teaching without further permission

For information on Institutional Fellowships contact consortiasales@bmjgroup.com

Visit casereports.bmj.com for more articles like this and to become a Fellow 